\title{
Human cathepsin D
}

\author{
Alina Minarowska ${ }^{1}$, Marek Gacko ${ }^{2}$, Alicja Karwowska ${ }^{3}$, Lukasz Minarowski ${ }^{4}$, \\ 13rd Department of Children's Diseases, Medical University of Bialystok, Poland \\ ${ }^{2}$ Department of Vascular Surgery, Medical University of Bialystok, Poland \\ ${ }^{3}$ Department of Instrumental Analysis, Medical University of Bialystok, Poland \\ ${ }^{4}$ Department of Lung Diseases and Tuberculosis, Medical University of Bialystok, Poland
}

\begin{abstract}
A literature survey was performed of human cathepsin D gene, cathepsin D biosynthesis, posttranslatory modifications, transport within the cell, substrate specificity and catalytic effect. Methods used to determine the activity and level of this proteinase as well as its role in the biochemistry and pathobiochemistry of cells, tissues and organs were considered.
\end{abstract}

Key words: Cathepsin D - Procathepsin D - Preprocathepsin D - Aspartic proteinase

The proteolytic activity in tissue extracts, reflected by acid $\mathrm{pH}$, was described by Hedin in 1904 [1]. In 1928, the term cathepsin (from the Greek word meaning "to digest") was introduced by Wilstätter and Bamann [2] to define the enzyme showing this activity. In 1937, Anson [3] designed a method for cathepsin purification and used hemoglobin as a substrate to determine its activity. In 1952, lysosomal peptidases were described and called cathepsin A, B and C [4]. In 1955, De Duve [5] presented lysosomes as the site of cathepsin action. In Poland, cathepsin D and its hemoglobin substrate were studied by Czystohorski as early as in the 50s [6]. In 1960, Press et al. [7] used the term cathepsin D to differentiate it from other endopeptidases and exopeptidases.

At present, cathepsin D (EC 3.4.23.5) is defined as lysosomal aspartyl endopeptidase. It breaks down proteins into several polypeptide fragments that digest other lysosomal endopeptidases and exopeptidases.

\section{Cathepsin D gene}

The cathepsin D gene is located at the end of the short arm of chromosome 11, in the p15.5 region, close to the H-ras oncogene (Fig. 1). It consists of 9 exons and contains 11.106 base pairs. For a complete sequence of cathepsin $\mathrm{D}$ gene please refer to paper by Roedecker et

Correspondence: L. Minarowski, Dept. of Lung Diseases and Tuberculosis, Medical University of Bialystok, Zurawia Str. 14, 15-540 Bialystok; tel.: (+4885) 73241 49,

fax.: (+4885) 73241 49, e-mail: lukmin@mp.pl al. [8]. Cathepsin D gene transcription leads to the formation of mRNA containing 1.988 bases. Its expression is regulated by steroid hormones, growth factors IGF-1, TNF- $\alpha$ and EGF and by retinoic acid [9-12]. Cathepsin D biosynthesis is inhibited by cycloheximide and colchicine [13-15].

\section{Occurrence, isolation and purification}

Cathepsin D can be found in nearly all cells, tissues and organs, but not in mature lysosome-free erythrocytes [16]. From tissue homogenate, cathepsin D is isolated and purified by means of ammonium sulphate saltation, organic solvent fractionation, molecular gel (sephadex) chromatography and ion-exchangeable chromatography. The terminal stages of purification involve affinity chromatography with application of pepstatin [1720], synthetic inhibitors [21], antibodies, cathepsin D propeptide and hemoglobin [22-24], which are bound to a constant carrier. Differences in the $\mathrm{pH}$ values between procathepsin $\mathrm{D}$ and cathepsin $\mathrm{D}$ binding to pepstatinyl-agarose allowed isolation of these two forms of the enzyme [25]. Cathepsin D inhibitors can be isolated by means of cathepsin D bound to a constant carrier [22]. Cathepsin D is also obtained using genetic engineering techniques [10,26-28].

The method of cathepsin $\mathrm{D}$ isolation from the human liver [29-33], spleen [18], brain [37], uterus [34], placenta [35], gastric mucosa [36], thyroid [38] and leucocytes [39] has been described. The human liver cathepsin D preparation is produced by Calbiochem and Sigma. 


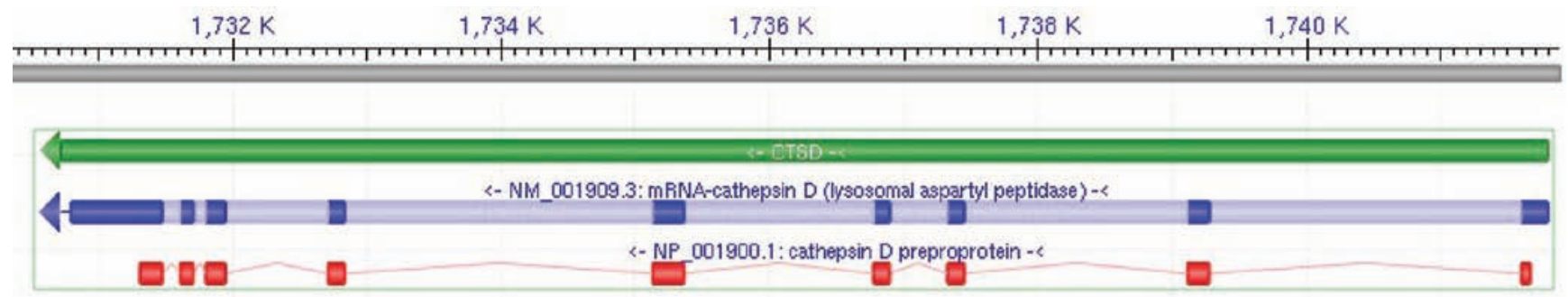

Fig. 1. Cathepsin D gene, GeneID: 1509 (description in text).

Thanks to the disordered structure of the polypeptide chain (in approximately $70 \%$ ) and the presence of four disulphate bridges and eight oligosaccharide chains, cathepsin D is well soluble and resistant to denaturating agents and proteolytic degradation [40-42].

\section{Biosynthesis}

Cathepsin D is synthesized in the form of preprocathepsin $[33,43-46]$ by the mRNA bound to the rough endoplasmic reticulum (RER). Translocation of preprocathepsin D to the cisterns of the endoplasmic reticulum (ER) is possible due to a signal sequence $[47,48]$. A signal recognition particle (SRP) binds to the sequence, at the same time blocking protein translation. Then, the SRP binds to its receptor, located in ER, which reactivates translation (Fig. 2). Binding of the SRP-receptor initiates the formation of hydrophylic protein channel in the ER membrane. Next, the SRP detaches from the complex and returns to the cytoplasm. Simultaneously, ribosomes bind to proteins of the ER membrane. The elongating polypeptide chain is introduced through the channel in the ER membrane to the cisterns due to a 20 amino acid sequence situated at

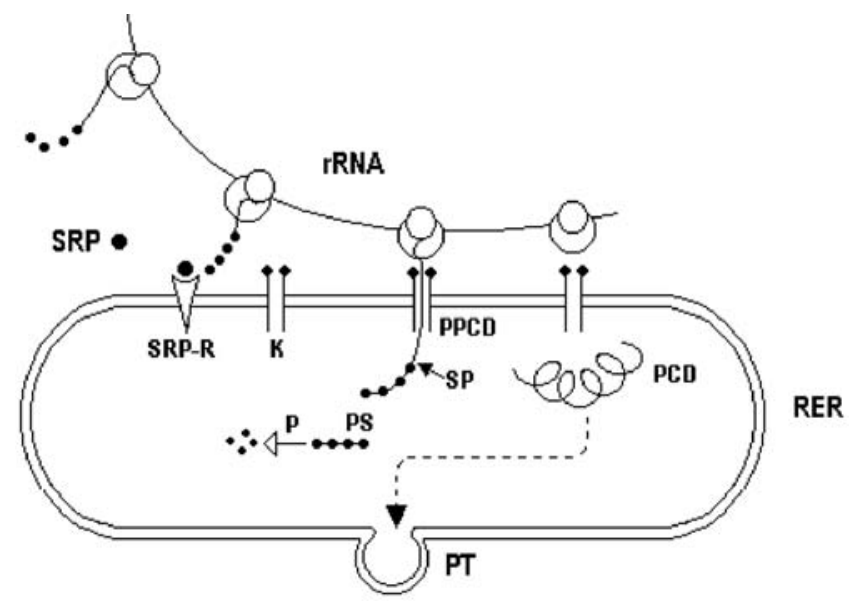

Fig. 2. Biosynthesis of preprocathepsin D (PPCD); synthesis and postralationnal modification of procathepsin D (PCD). K - endoplasmic reticulum membrane channel; P - PS cleaving protease; PCD - procathepsin D;PPCD - preprocathepsin D; PS - signaling peptide; PT - transport vesicle; RER - rough endoplasmic reticulum; SP - signal peptidase; SRP - signal-recognition particle; SRP$\mathrm{R}$ - SRP receptor. the N-terminus. At the end of this channel, signal peptidase in ER cisterns cuts off the signal sequence, thus leading to the generation of procathepsin D that enters the ER cisterns. The signal sequence that has been detached undergoes degradation to amino acids. The amino acid sequence of procathepsin D determines its posttranslatory modifications: particle rugosity, formation of disulphate bridges, N-glycosylation and phosphorylation. About $5 \%$ of the polypeptide chain of procathepsin D has an alpha-helix conformation, 26\%beta conformation (rugose sheet), and the remaining part being a disordered structure. Disulphate bridges are formed between the cysteine residues Cys27Cys96, Cys46-Cys53, Cys222-Cys226 and Cys265Cys302, their location being determined by proteindisulphide isomerase (PDI). The N-glycosylation site is constituted by the Asn70 residue (heavy chain) and Asn199 residue (light chain) of the molecule.

\section{Glycosylation}

The oligoglycosylation chains are synthesized with the involvement of dolichol phosphate and then transferred onto asparagin residues [46,78], located on the triad sequences: Asn70-Gly71-Thr72 and Asn199Val200-Phe201. The remaining 9/11 asparagin residues are not found on these sequences and are subject to glycolysation. Cathepsin D contains eight various mannose type oligosaccharide chains in the particle (Fig. 3). Five of them bind to the residue Asn-70 of the light chain and contain 3, 5, 6 or 7 mannose residues. All of them contain two GlcNAc, one has three GlcNAc residues. Three oligosaccharides bind to the residue Asn199 of the heavy chain and contain 5 mannose residues. One of them has three GlcNAc residues, one contains fucose and one has galactose. Each oligosaccharide chain contains two N-acetylglucosamine molecules, whereas two of them have 3 molecules and from 3 to 7 mannose residues.

The phosphate acid residue is attached to the sixth carbon of mannose [81], which conditions binding to the mannose-6-phosphate receptor and translocation of cathepsin $\mathrm{D}$ to primary lysosomes. The GlcNAc residues found outside the oligosaccharide chain are not subject to phosphorylation and are not involved in the transport of cathepsin D. 

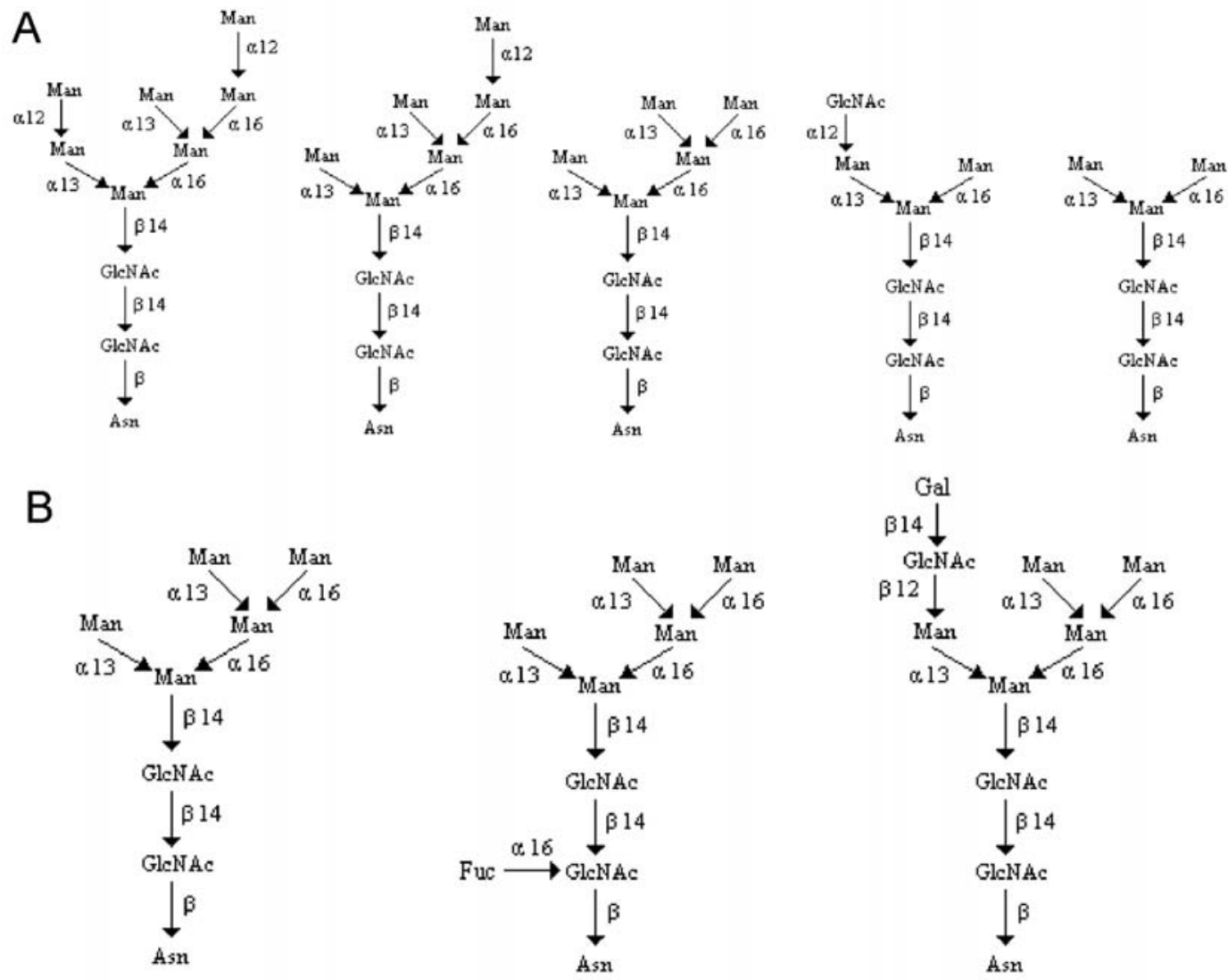

Fig. 3. Oligosaccharide chains found in cathepsin [51]; (A) oligosaccharides linked with Asn70 in the heavy chain; (B) oligosaccharides linked with Asn199 in the light chain. Asn - asparagine, Fuc - fucose, Gal - galactose, GlcNAc - N-Acetyl-D-glucosamine, Man - mannose.

\section{Phosphorylation and binding to the receptor}

The cis zone of the Golgi apparatus captures ERderived transport vesicles that contain glycosylated procathepsin $\mathrm{D}$, which is then transferred to its central and trans zones. In the trans zone, terminal mannose residues undergo phosphorylation to mannose-6-phosphate (M6P) $[53,54]$. By means of M6P residues, procathepsin D binds to mannose-6-phosphate receptors (M6PR) and in the form of vesicles is transported to primary lysosomes [55-60]. Primary lysosomes are formed by budding off from the membrane fragment of the smooth endoplasmic reticulum. The mannose6-phosphate receptor (M6PR) is a heterogenic protein and occurs in two types: M6PR-46 and M6PR-300. The action of M6PR-46 (46 kDa) depends on the presence of bivalent cations, whereas that of M6PR-300 $(300 \mathrm{kDa})$ is not bivalent cation-dependent. In the acid environment of primary lysosomes $(\mathrm{pH}=4.5-5.5)$, the procathepsin D M6P-M6PR complex undergoes dissociation. The receptor returns to the Golgi apparatus and transports M6P molecules of procathepsin D, whereas the receptor-free procathepsin D remains in lysosomes and undergoes dephosphorylation. The mannose-6phosphate receptors occur in the trans-Golgi network and in primary lysosomes, but not in mature lysosomes. These differences help distinguish primary from mature lysosomes.

\section{Proteolytic transformations}

Preprocathepsin D is composed of 412 amino acid residues [63-68]. In its molecule, signal protease cleaves the peptide bond Ala20-Leu21 and 20-amino acid prepeptide is split off (Fig. 4), giving rise to procathepsin D, built up of 392-amino acid residues. Its autocatalytic activation takes place in primary lyso-

1

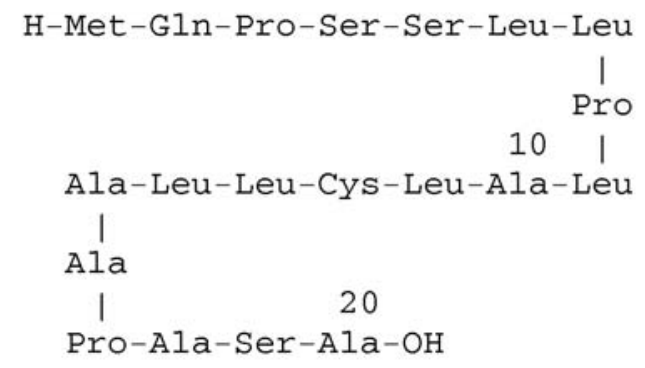

Fig. 4. Cathepsin D prepeptide (signaling sequence). 


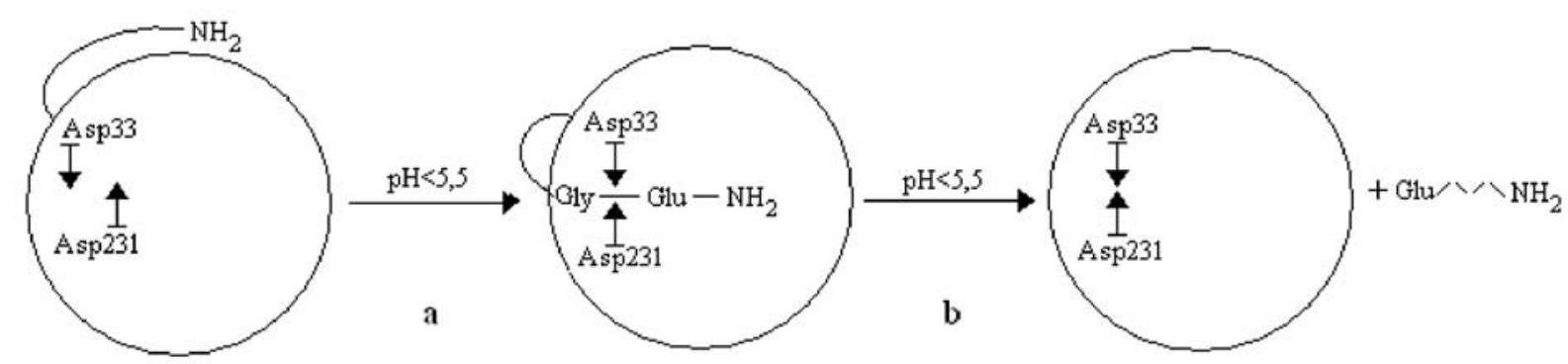

Fig. 5. Autoactivation of procathepsin D; (a) conformational changes and formation of catalytic site (formed by Asp33 and Asp231); (b) autoactivation, splitting-off of activating peptide.

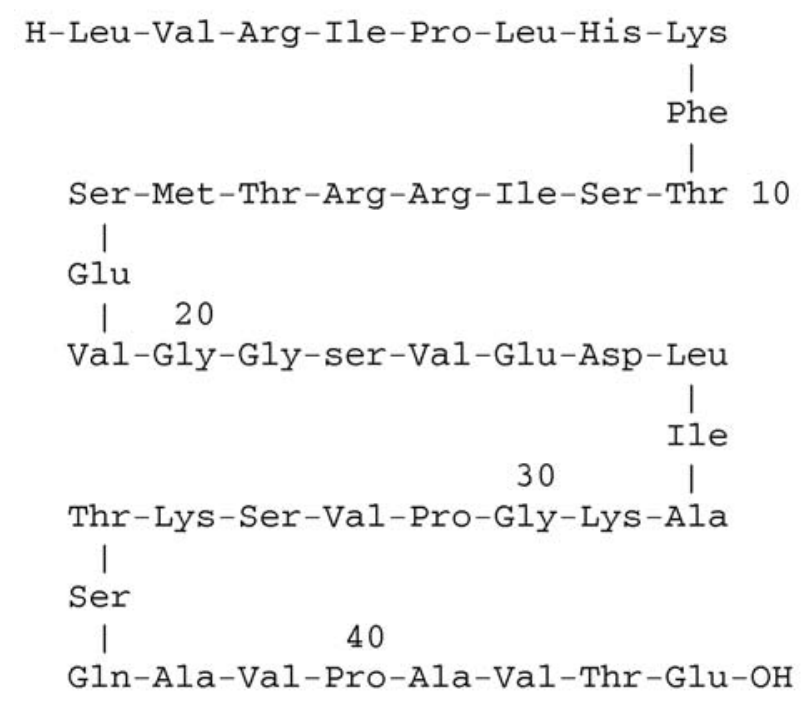

Fig. 6. Cathepsin D propeptide.

somes, in an acidic pH (Fig. 5). Intracellular cleavage of the Glu64-Gly65 bond and splitting-off of 44-amino acid propeptide occur (Fig. 6). An active mono-chain form of cathepsin D, composed of 348 amino acid residues, is generated (Fig. 7). The enumeration of amino acid residues of the mono-chain cathepsin D (from 1 to 348) has been used for tracing further transformations in the polypeptide chain. A non-defined endopeptidase cleaves the -Val6-Leu7- bond and the 6amino acid fragment of the Ser-Ala-Ser-Ser-Ala-Val sequence is split off, giving rise to a molecule built up of 342 amino acid residues. The aminopeptidase cleaves the Leu7-Lys8- bond and a leucine residue is split off. A modified mono-chain cathepsin D molecule, composed of 341 amino acid residues, is produced, in which cysteine endopeptidase cleaves the -Ala204-Tyr205- bond. A two-chain cathepsin D molecule is produced, with no change in the number of amino acid residues. The heavy chain contains 204, whereas the light chain - 137 amino acid residues. Inhibitors for cysteine proteinases prevent this transformation [43,69,70]. Carboxypeptidase cleaves the Lys203-Ala204 bond and the Ala204 residue is split off the heavy chain C-terminus. Aminopeptidase cleaves the Tyr205-Trp206 bond and the Tyr205 residue is split off the light chain N-terminus. Carboxypeptidase cleaves in turn the Arg347-Lys348 and then Ala346-Arg347 bonds and the residues Lys348 and Arg347 are split off the C-terminus of the light subunit. These protease inhibitors suppress cathepsin D maturation. The ultimate form of mature two-chain cathepsin $\mathrm{D}$ is composed of 337 amino acid residues. The heavy chain contains 196 and the light chain has 141 amino acid residues. These chains are linked by hydrophobic bonds (Fig. 8). The amino acid composition shows a substantial content of glycine and an approximately twofold level of dicarboxy amino acids and their amides as compared to alkaline amino acids (Table 1).

The proteolytic activation of procathepsin $\mathrm{D}$ via limited proteolysis is an irreversible process. An ultimate cathepsin D molecule has an approximate double symmetry. The proteolytic activity of the mono-chain and two-chain forms is the same (Fig. 9).

Proteolytic modifications of the molecule and diversity of oligosaccharide composition contribute to a marked molecular heterogenicity of cathepsin D $[17,29,37,71,72]$.

\section{Substrate specificity}

Cathepsin D cleaves peptide bonds inside the polypeptide chain. These bonds are formed mainly by carboxyl groups of hydrophobic amino acids, especially aromatic amino acids $[73,74]$.

Research studies performed with synthetic peptides (general formula Fig. 10) have provided information on the structure of the catalytic site of cathepsin D and the requirements each substrate should fulfill. The peptides contain different amino acid residues at positions $\mathrm{X}$ and Y. Only the peptides that have amino acids with ramified chains in the $\mathrm{X}$-position are resistant to hydrolysis. Those containing at least five amino acid residues in a molecule are sensitive to cathepsin D effect. In the hexapeptide containing the sequence of Gly1-Phe2-Phe3-Tyr4-Thr5-Pro6-Lys7, cathepsin D cleaves two peptide bonds between Phe2-Phe3 and Phe3-Tyr4, whereas in the heptapeptide Phe1-Gly2His3-Nph4-Phe5-Val6-Leu7-OMe the bond between Nph4-Phe5 is cleaved [76]. In micromolecular syn- 
1

15

- Asp-Ala-Gln-Tyr $16 \quad 30$ Tyr-Gly-Glu-Ile-Gly-Ile-Gly-Thr-Pro-Pro-Gln-Cys-Phe-Thr-Val31 Val-Phe-Asp-Thr-Gly-Ser-Ser-Asn-Leu-Trp-Val-Pro-Ser-Ile-His$46 \quad 60$ Cys-Lys-Leu-Leu-Asp-Ile-Ala-Cys-Trp-Ile-His-His-Lys-Tyr-Asn$61 \quad 75$ Ser-Asp-Lys-Ser-Ser-Thr-Tyr-Val-Lys-Asn-Gly-Thr-Ser-Phe-Asp$76 \quad 90$ Ile-His-Tyr-Gly-Ser-Gly-Ser-Leu-Ser-Gly-Tyr-Leu-Ser-Gln-Asp$91 \quad 105$ Thr-Val-Ser-Val-Pro-Cys-Gln-Ser-Ala-Ser-Ser-Ala-Ser-Ala-Leu$106 \quad 120$ Gly-Gly-Val-Lys-Val-Glu-Arg-Gln-Val-Phe-Gly-Glu-Ala-Thr-Lys$121 \quad 135$

Gln-Pro-Gly-Ile-Thr-Phe-Ile-Ala-Ala-Lys-Phe-Asp-Gly-Ile-Leu$136 \quad 150$

Gly-Met-Ala-Tyr-Pro-Arg-Ile-Ser-Val-Asn-Asn-Val-Leu-Pro-Val$151 \quad 165$

Phe-Asp-Asn-Leu-Met-Gln-Gln-Lys-Leu-Val-Asp-Gln-Asn-Ile-Phe166180

Ser-Phe-Tyr-Leu-Ser-Arg-Asp-Pro-Asp-Ala-Gln-Pro-Gly-Gly-Glu$181 \quad 195$

Leu-Met-Leu-Gly-Gly-Thr-Asp-Ser-Lys-Tyr-Tyr-Lys-Gly-Ser-Leu$196 \quad 210$

Ser-Tyr-Leu-Asn-Val-Thr-Arg-Lys-Ala-Tyr-Trp-Gln-Val-His-Leu-

Fig. 7. Aminoacidic sequence of human, single-chain cathepsin D [46]; * - catalytic site - Asp33 and Asp231 residues; - catalytic site Asn70 and Asn199 with added oligosaccharide chains. thetic substrates the number of peptide bonds cleaved by cathepsin $\mathrm{D}$ is considerably smaller even though they are formed by the same amino acid residues. The differences are due to additional sites in the enzyme molecule that bind macromolecular substrates [74,77].

In the oxidized insulin chain B, cathepsin D cleaves five peptide bonds, whereas all proteases of lysosomal extracts cleave as many as $27 / 29$ peptide bonds in this polypeptide (Fig. 11). The peptide bonds cleaved by cathepsin D in some proteins have been presented in Table 2.

\section{Mechanism}

The catalytic site of cathepsin D is constituted by two asparagine acid residues - Asp33 and Asp231, located in the triad sequences of Asp-33-Thr34-Gly35 and Asp31-Thr232-Gly233 [80]. In the acidic environment, the carboxyl group of Asp33 undergoes dissociation, whereas that of Asp231 does not. The carboxyl group of Asp33 activates the water molecule and allows proton release from this molecule. However, the protonated carboxyl group of Asp231 polarizes the carbonyl group of the peptide bond, facilitates formation of a tetraedric intermediate and allows cleavage of the bond. The reactions are performed by ionizing groups of cathepsin D and therefore their velocity is $\mathrm{pH}$-dependent. Cathepsin D shows the highest activity in an acidic $\mathrm{pH}(\mathrm{pH}=3.5-5.5)$.

Hydrolysis of the peptide bonds catalyzed by cathepsin D occurs in two stages and can be expressed as a general formula (Fig. 12). In the first stage, the 

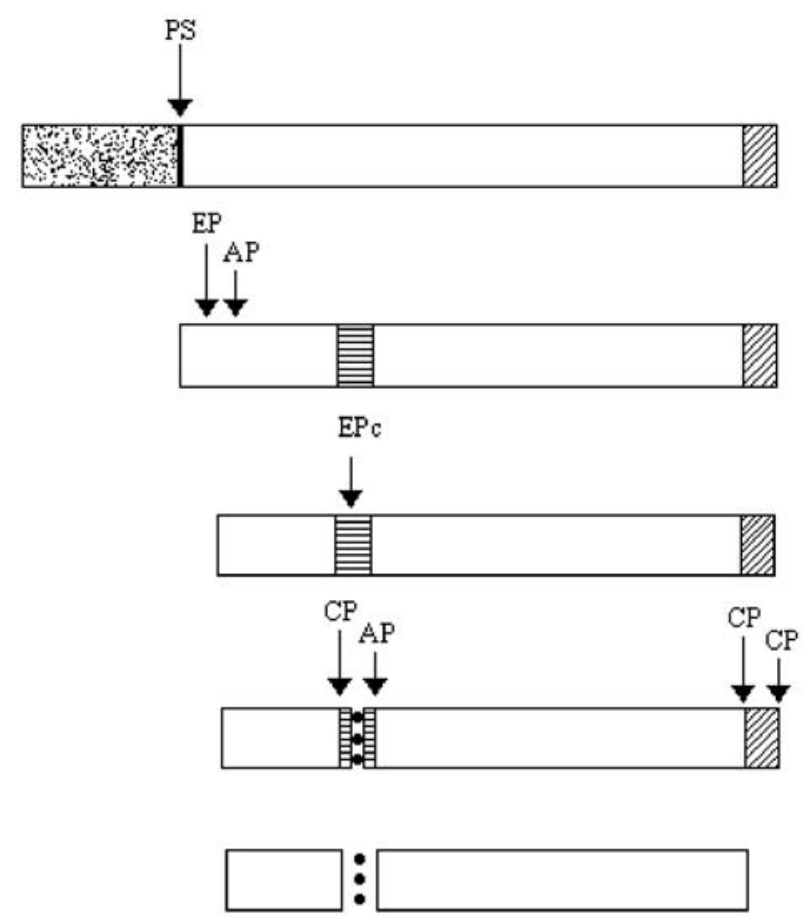

Fig. 8. Proteolytic modification of procathepsin D. PS - signaling peptide, EP - endopeptidase, AP - aminopeptidase, EPc - cysteinyl endopeptidase, CP - carboxypeptidase, : - hydrophobic bond.

enzyme (E) binds water and with a substrate (S) forms the enzyme-substrate complex (E-S), in which the components are bound by ionic and hydrogen bonds. Conformatory changes, intramolecular electron and proton regrouping within the peptide bond are observed, and a covalent intermediate compound (E$\left.\mathrm{S}^{\prime}\right)$ is formed. The intermediate compound is an aminoacyl enzyme. In the next stage, the intermediate compound undergoes breakdown, accompanied by the release of the first (R1) and the second (R2) reaction products.

The action of cathepsin D takes place not only with the involvement of asparagine acid residues but also with other amino acid residues, and it thus has a multifunctional and intracellular character. Multifunctional catalysis is based on simultaneous effects of nucleophylic and electrophylic groups of the enzyme catalytic site on the carbonyl group of the peptide bond. Attachment of the substrate is followed by two synchronized transfer reactions: in the first, the proton is transferred from a water molecule onto a carboxyl anion of Asp33, in the other, the proton derived from a carboxyl group of Asp231 is transferred onto the oxygen of the carbonyl group of the substrate, giving rise to a tetraedric intermediate [81-86].

Two protons are simultaneously transferred onto the peptide bond (Fig. 13a). The first originates from the water molecule activated by Asp33. The other is derived from the carboxyl group of Asp231 and is carried onto the oxygen atom of the carbonyl group of the
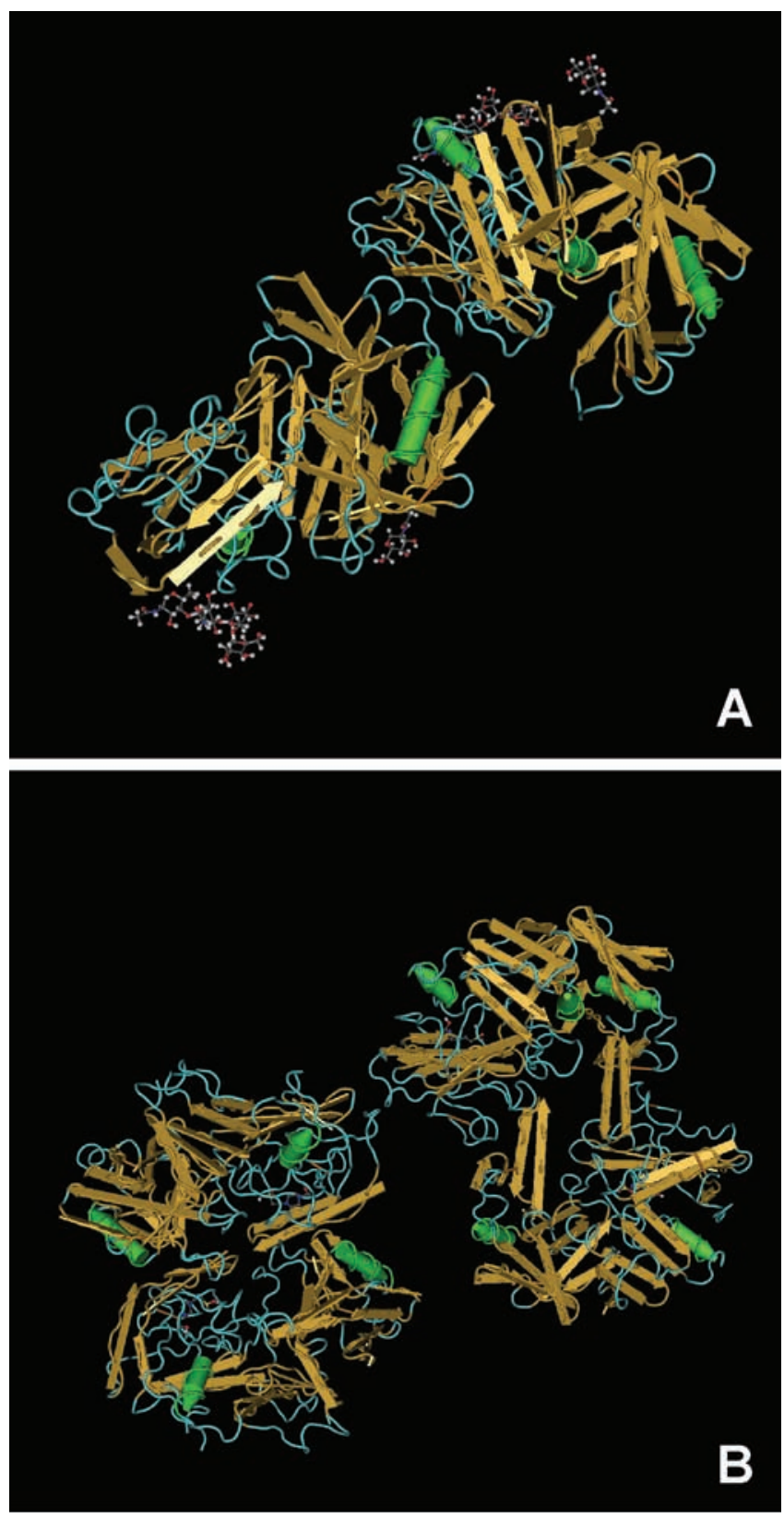

Fig. 9. 3D structure of human cathepsin D in active (A) [171] and inactive form $(\mathbf{B})$ in $\mathrm{pH}=7.5$ [172].

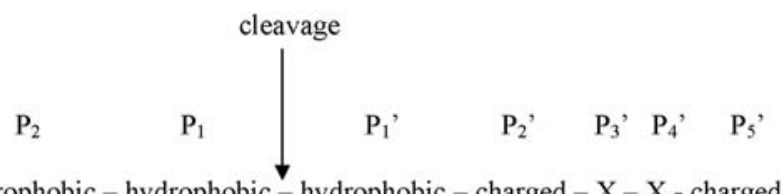

hydrophobic - hydrophobic - hydrophobic - charged - X - X - charged

$$
\text { (Leu/aromatic) (basic) (basic) }
$$

Fig. 10. Amino acid sequence pattern common for oligoproteins that are preferentially cleaved by cathepsin D [75].

peptide bond. These two transfers lead to the formation of an aminoacyl enzyme, being a tetraedric intermediate (Fig. 13b), sensitive to the action of the activated water molecule. The subsequent double proton transfer causes 
Table 1. Amino acid composition of different molecular forms of cathepsin D.

\begin{tabular}{|c|c|c|c|c|c|c|c|}
\hline \multirow{2}{*}{ Aminoacid } & \multirow{2}{*}{ Prepro } & \multirow{2}{*}{ Prepeptide } & \multirow{2}{*}{ Procathepsin } & \multirow{2}{*}{ Propeptide } & \multirow{2}{*}{$\begin{array}{l}\text { One-chain } \\
\text { cathepsin }\end{array}$} & \multicolumn{2}{|c|}{ Two-chain cathepsin } \\
\hline & & & & & & Heavy chain & Light chain \\
\hline Ala A & 28 & 5 & 23 & 3 & 20 & 11 & 9 \\
\hline $\operatorname{Arg} R$ & 12 & & 12 & 3 & 9 & 4 & 4 \\
\hline Asn $\mathrm{N}$ & 11 & & 11 & & 11 & 9 & 2 \\
\hline Asp D & 21 & & 21 & 1 & 20 & 12 & 8 \\
\hline Cys C & 9 & 1 & 8 & & 8 & 4 & 4 \\
\hline Glu E & 17 & & 17 & 3 & 14 & 4 & 9 \\
\hline $\mathrm{G} \ln \mathrm{Q}$ & 17 & 1 & 16 & 1 & 15 & 10 & 5 \\
\hline Gly G & 39 & & 39 & 3 & 36 & 19 & 16 \\
\hline His $\mathrm{H}$ & 6 & & 6 & 1 & 5 & 4 & 1 \\
\hline Ile I & 23 & & 23 & 3 & 20 & 11 & 8 \\
\hline Leu L & 41 & 6 & 35 & 3 & 32 & 15 & 15 \\
\hline Lys K & 23 & & 23 & 3 & 20 & 11 & 8 \\
\hline Met M & 10 & 1 & 9 & 1 & 8 & 4 & 4 \\
\hline Phe F & 14 & & 14 & 1 & 13 & 9 & 4 \\
\hline Pro P & 26 & 3 & 23 & 3 & 20 & 9 & 9 \\
\hline Ser S & 37 & 3 & 34 & 5 & 29 & 22 & 7 \\
\hline Thr T & 21 & & 21 & 3 & 18 & 10 & 8 \\
\hline Trp W & 4 & & 4 & & 4 & 2 & 2 \\
\hline Tyr Y & 19 & & 19 & 1 & 18 & 12 & 5 \\
\hline Val V & 34 & & 34 & 6 & 28 & 14 & 13 \\
\hline Sum & 412 & 20 & 392 & 44 & 348 & 196 & 141 \\
\hline $\mathrm{Mr}, \mathrm{kDa} *$ & 44550 & 1967 & 42601 & 4768 & 37850 & 21381 & 15181 \\
\hline
\end{tabular}

*calculated from amino acid composition, without sugar moieties.

breakdown of the tetraedric intermediate (Fig. 13c). The intra- and mono-molecular character ensures the maximum concentration of the catalytic groups, their optimal direction and spatial distribution. In consequence, these processes reduce the activation energy (Fig. 14). The peptide bond of the C-N substrate is broken down, which gives rise to the first product of reaction with a free carboxyl group (R1) and to an aminoenzyme. Then, the second product of reaction with a free amine group is released (R2). The catalytic site of cathepsin D changes into the anhydride form, which undergoes rapid hydrolysis and is thus reproduced as the primary structure of the catalytic site.

Pepstatin, a pentapeptide containing statin at position 4 (Sta4) was used to investigate the structure of the catalytic site. The Sta4 residue is a structural analog of

Cathepsin D
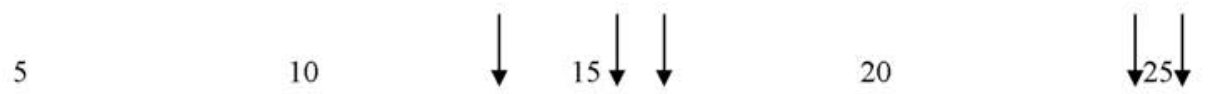

Phe-Val-Asn-Gln-His-Leu-Cys-Gly-Ser-His-Leu-Val-Glu-Ala-Leu-Tyr-Leu-Val-Cys-Gly-Glu-Arg-Gly-Phe-Phe-Tyr-Thr-Pro-Lys-Ala

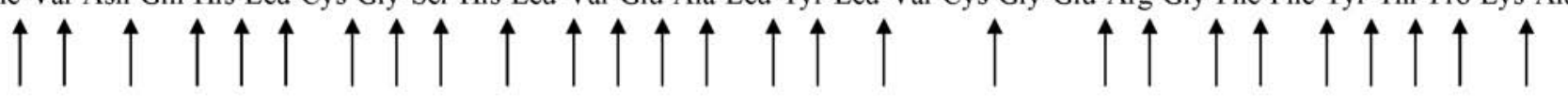

Lysosomal extracts

Fig. 11. Cleavage of B-chain of insulin by cathepsin D and lysosomal extracts [78,79]. 
Table 2. Preferential cleavage sites in various protein substrates found upon mild cleavage by cathepsin D [75]. Homologous amino acid residues at the various positions are enclosed by boxes.

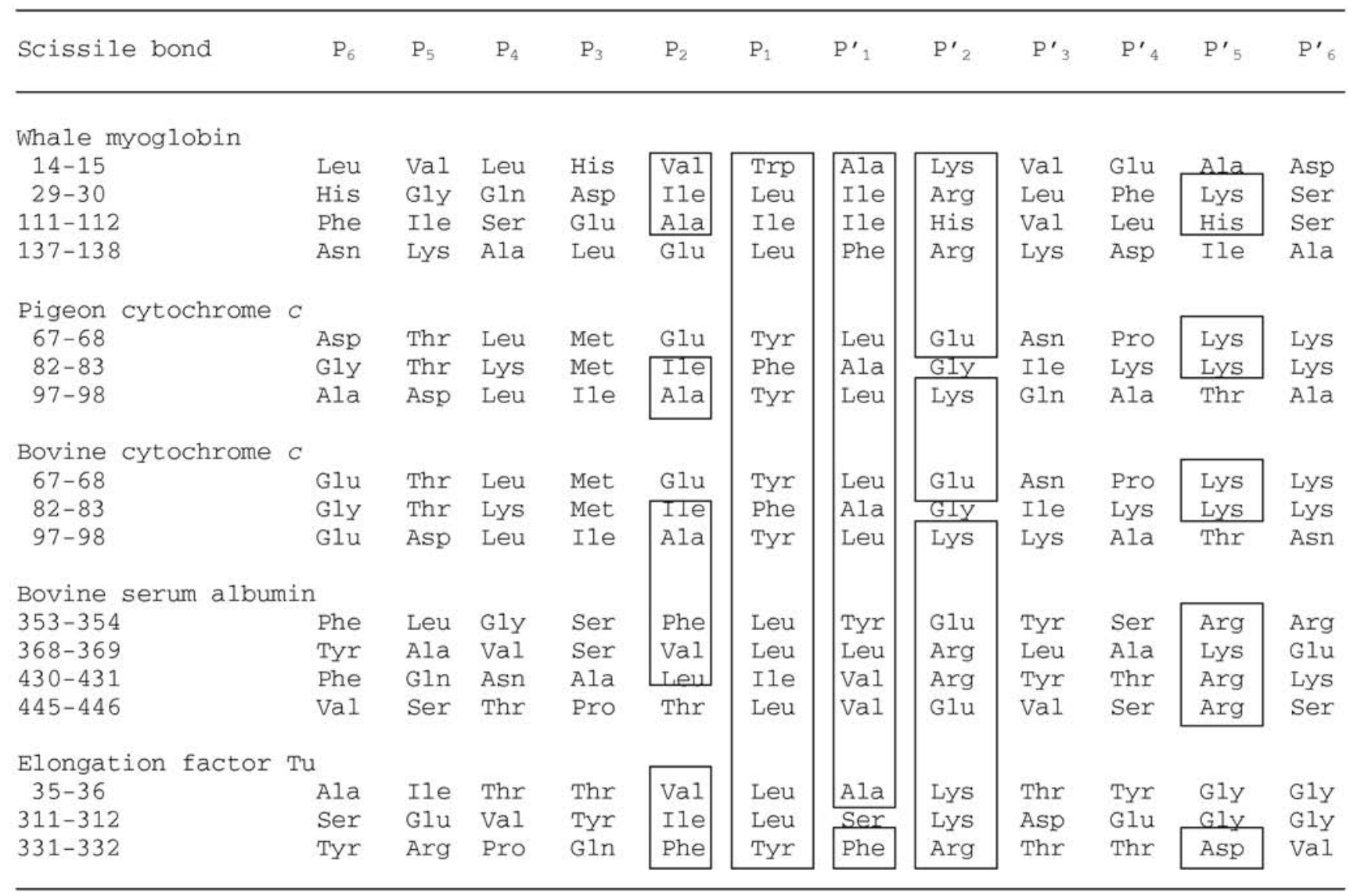<smiles>[R1]C(=O)OCC</smiles>

Fig. 12. Simplified diagram presenting hydrolysis of peptide bond.

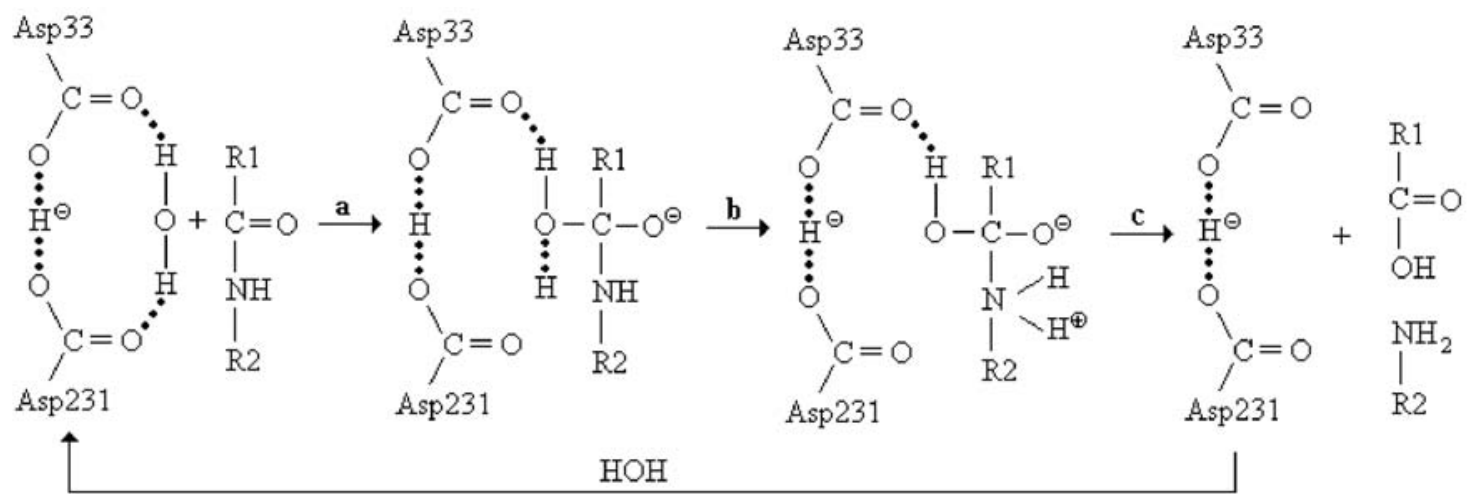

Fig. 13. Cathepsins D mechanism of action: (a) transfer of two protons, (b) formation of tetraedric intermediate, (c) breakdown of the tetraedric intermediate. 


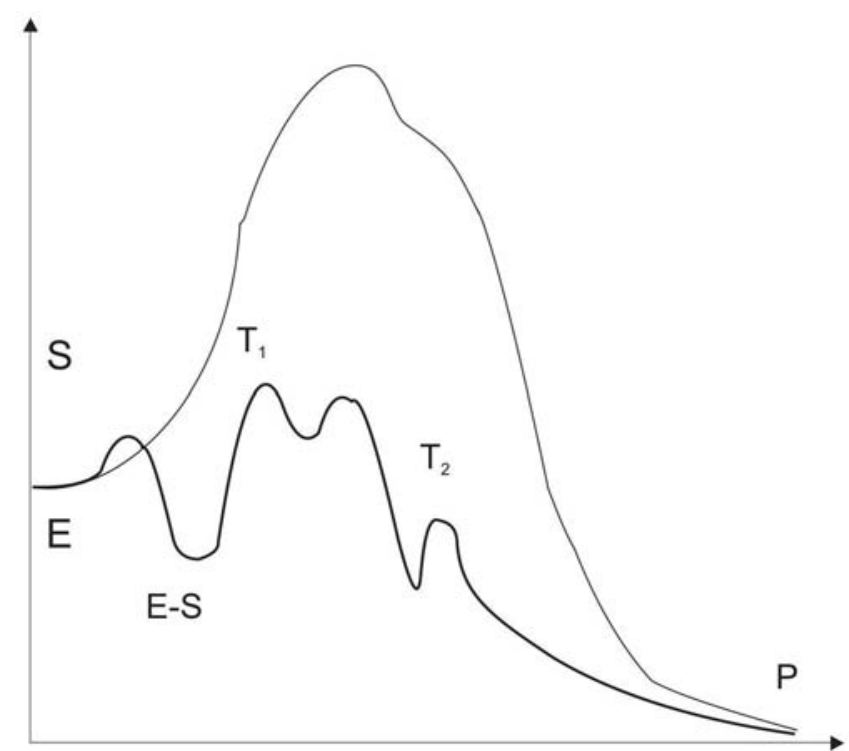

Fig. 14. Diagrammatic representation of the free activation energy of peptic bond hydrolysis catalyzed by cathepsin D. E - enzyme, S - substrate, E-S enzyme-substrate complex, T1, T2 - tetraedric intermediate, P - product. Upper line - non-catalyzed reaction, lower line - catalyzed reaction.

the substrate and of the transitory state, and exerts an inhibitory effect due to structural similarity to the tetraedric intermediate, formed during cleavage of peptide bond by asparagin acid residues of the catalytic site (Fig. 15). The interaction of cathepsin D with pepstatin is illustrated by a spatial model (Fig. 16).

\section{Activators and inhibitors}

The activity of cathepsin D is increased by glycine ethyl ester [90], phospholipids [91], polyphosphates

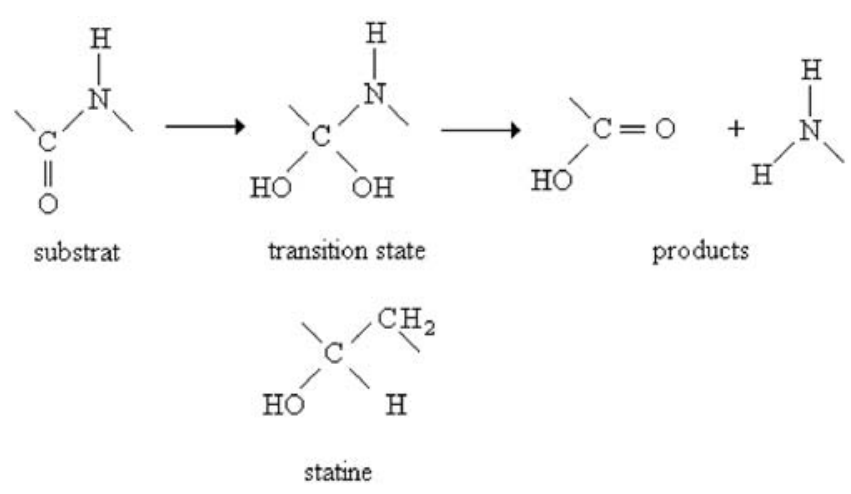

Fig. 15. Sta4 structural analogy to transition state of cathepsin D [83].

[92] and probably by a protein activator (20000 Da) isolated from the spleen [93]. The role of activating compounds in studies on cathepsin D is slight.

No typical cell cathepsin D inhibitors have been revealed. The inhibitory effect is demonstrated by a propeptide split off during procathepsin D autoactivation $[73,94,95]$ and by respective fragments of its structure [96]. Alpha2-macroglobulin is an endogenous plasma inhibitor of this protease [97,98]. The activity is also suppressed by antibodies $[99,100]$, some glycosaminoglycans [101] and fragments of DNA structure [102]. 1,2-epoksy3-(p-nitrofenyloksy)propan reacting with Asp33 [103] and methyl ester of diacetylo-DL-norleucine reacting with Asp231 are the synthetic inhibitors of cathepsin D [104]. Cathepsin D inhibitors, called pepstatins, are synthesized by bacteria of the genus Streptomyces [105-107]. Polypeptide inhibitors of this proteinase occur in spare organs of many plants [108] and in tissues of some lower ani-

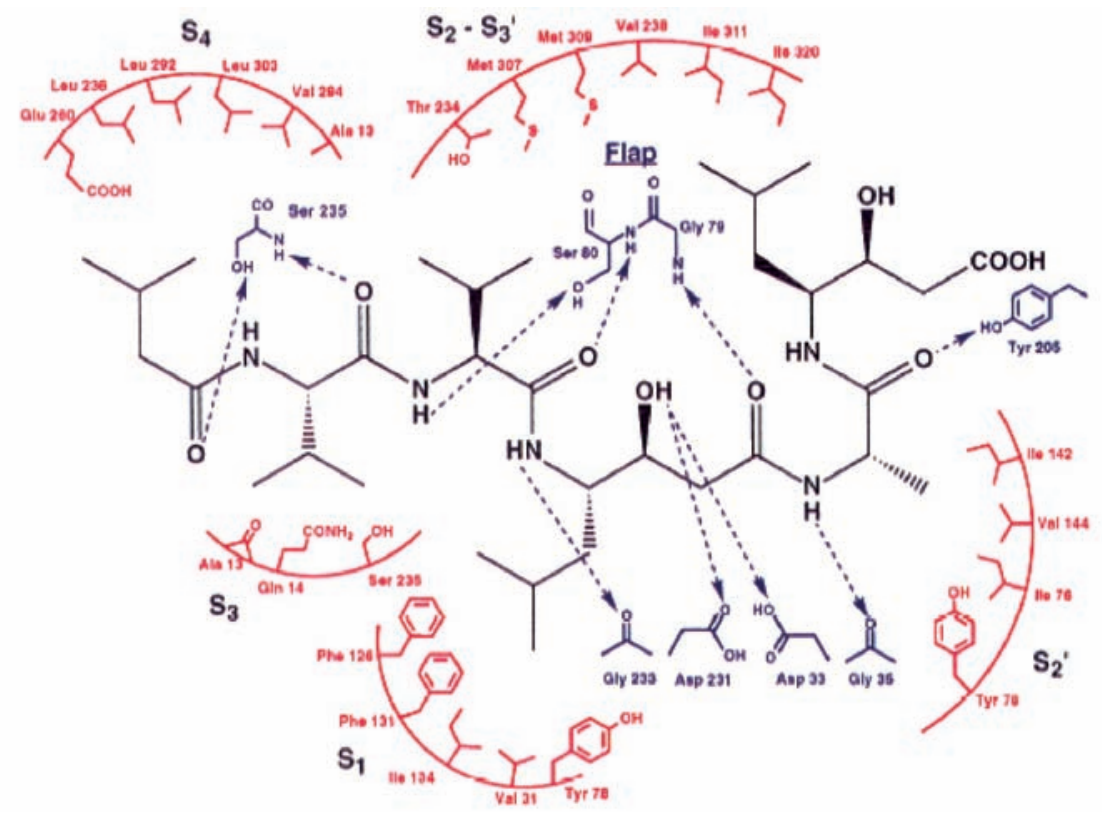

Fig. 16. Schematic diagram of the pepstatin A binding site in cathepsin D [89]. 


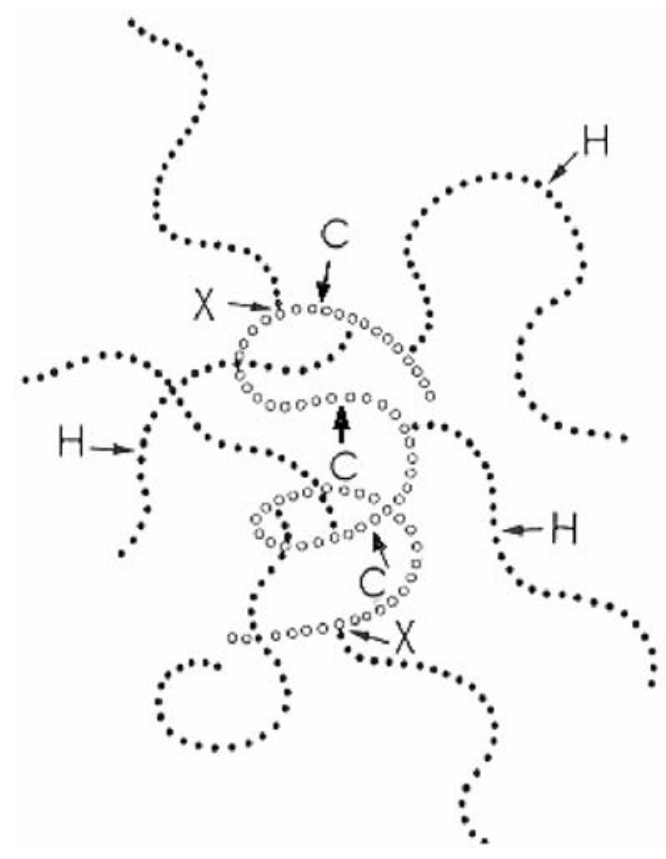

Fig. 17. Site of enzymes action on proteoglycans [121]. o-o-o protein core; -.•-• polysaccharide chain; C - cathepsin D; H hialuronidase; $X$ - $\beta$-xylosidase.

mals $[109,110]$. Cathepsin D inhibitors have played a substantial role in the studies concerning the structure and mechanism of action of this protease and its tissue location [111-115].

The effects of cathepsin D also depend on the structure of substrate protein. Denaturated or heme-free hemoglobin shows increased susceptibility to the
Table 3. Comparison of proteolytic activity of cathepsin D in degradation of various proteins [139].

\begin{tabular}{|l|c|}
\hline \multicolumn{1}{|c|}{ Protein } & Cathepsin D activity (\%) \\
\hline Hemoglobin (bovine) & 100.0 \\
\hline$\alpha$-globulin (bovine) & 16.5 \\
\hline$\beta$-globulin (bovine) & 15.0 \\
\hline Serum albumin (bovine) & 14.5 \\
\hline Collagen & 9.0 \\
\hline Fibrinogen & 7.5 \\
\hline Fibrin & 7.5 \\
\hline Serum albumin (human) & 7.5 \\
\hline Egg albumin & 3.5 \\
\hline$\gamma$-globulin (bovine) & 3.5 \\
\hline
\end{tabular}

action of this proteinase as compared to native hemoglobin [18]. However, hemoglobin complexification with haptoglobin reduces its susceptibility to cathepsin D [116].

\section{Role in protein degradation}

Cathepsin D takes part in digestion of exhausted and denaturated cell proteins or proteins showing abnormal structure and those which entered the cell via endocytosis $[14,25,26,96]$. It initiates proteolytic degradation of proteins, cleaving it into large fragments. This causes increased accessibility of the subsequent peptide bonds and thus they are further digest-

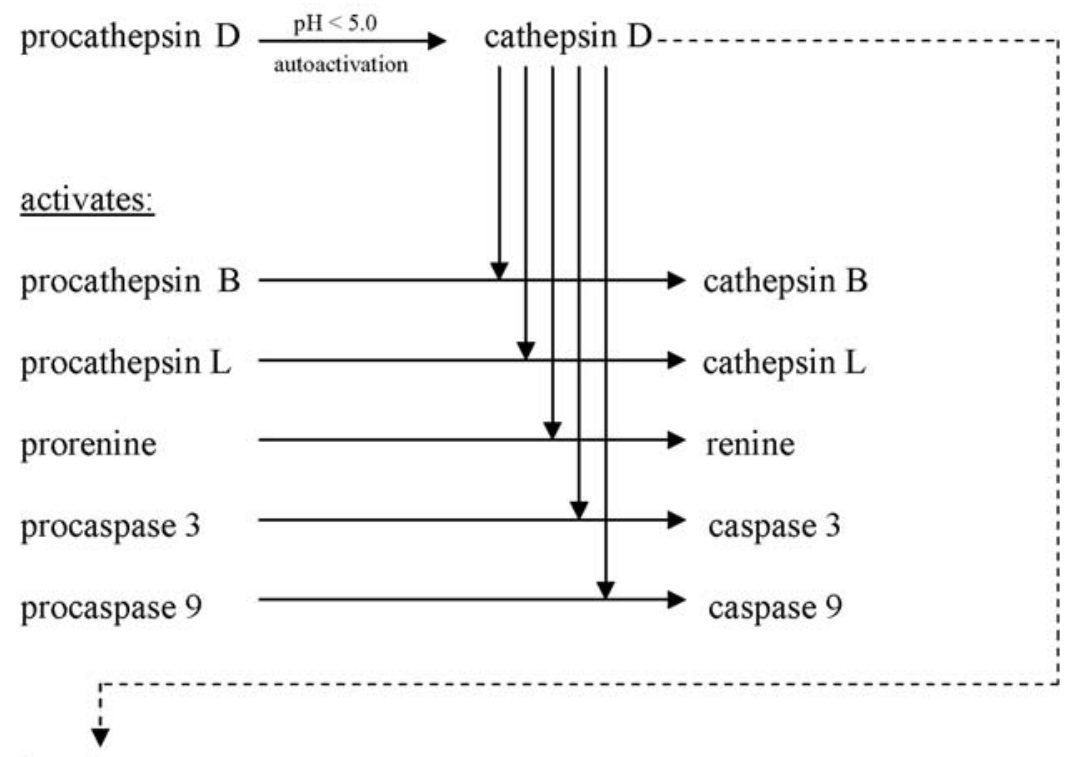

inactivates:

$\alpha_{1}$-antichymotrypsine, $\alpha_{1}$-antitrypsine, cystatines, plasminogen activator inhibitor- 1 , kallikrein inhibitor, seryl protease inhibitor 1-2, urokinase inhibitor 1-3, stefines.
Fig. 18. Activation of proenzymes and inactivation of proteinase inhibitors by cathepsin D [123128]. 


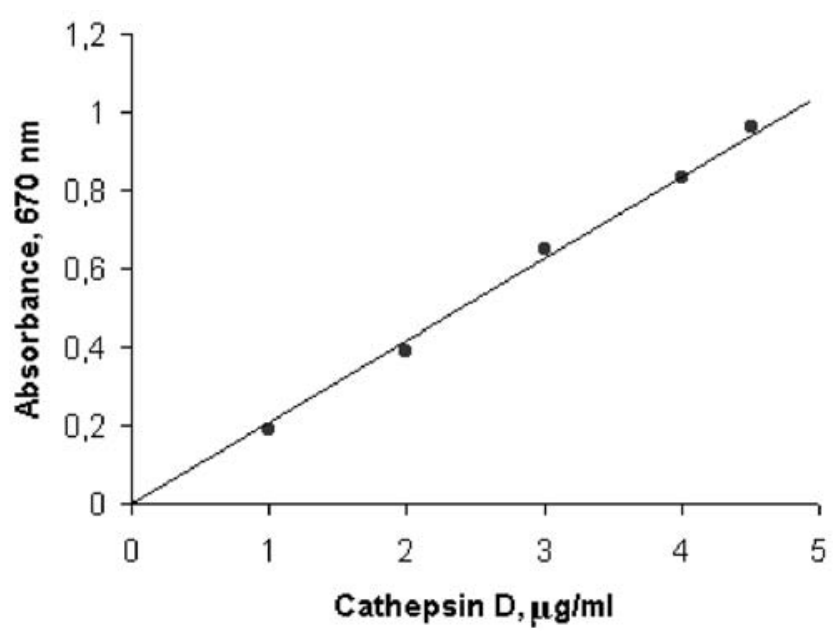

Fig. 19. The relationship between the hydrolysis of hemoglobin by cathepsin D on the amount of enzyme.

ed by other lysosomal proteins to dipeptides and amino acids. Cleavage of even a single peptide bond in a protein molecule may cause its structural denaturation and functional inactivation. The state of the protein molecule (native, denaturated) defines accessibility of the protease peptide bonds. In proteoglycans, cathepsin D cleaves peptide bonds located in the central part of the polypetide chains (Fig. 17), which results in the formation of large peptide glycan fragments. Collagen is also sensitive to the action of cathepsin D [122].

Cathepsin D also performs a limited proteolysis, referring to single peptide bonds, thus leading to the activation of proenzymes of certain proteases and inactivation of their inhibitors (Fig. 18). It is also involved in the conversion of prohormones and precursor forms of biologically active peptides to active forms [132] and contributes to their inactivation. (Table 3). From hemoglobin, cathepsin $\mathrm{D}$ releases biologically active hemorphins $[131,132]$. Thus, it plays a regulatory role.

The optimum $\mathrm{pH}$ for the action of cathepsin $\mathrm{D}$ bound to the lysosomal membranes is higher as compared to the free enzyme [133]. Also cathepsin D bound in vitro by a constant carrier shows higher $\mathrm{pH}$ optimum [134]. A small amount of cathepsin D can be found on cell surface, due to the fusion of lysosomes with the plasma membrane, it also enters the intercellular environment and passes to the blood [135].

\section{Determination of cathepsin D activity and concentration}

Cathepsin D does not need activators in order to act and has no endogenous inhibitors. Procathepsin D present in a sample undergoes rapid autoactivation in test conditions $(\mathrm{pH}=3.5-4.0)$ and therefore total activity of cathepsin D can be determined in the material examined. Bovine globin $[136,137]$ and bovine hemo-

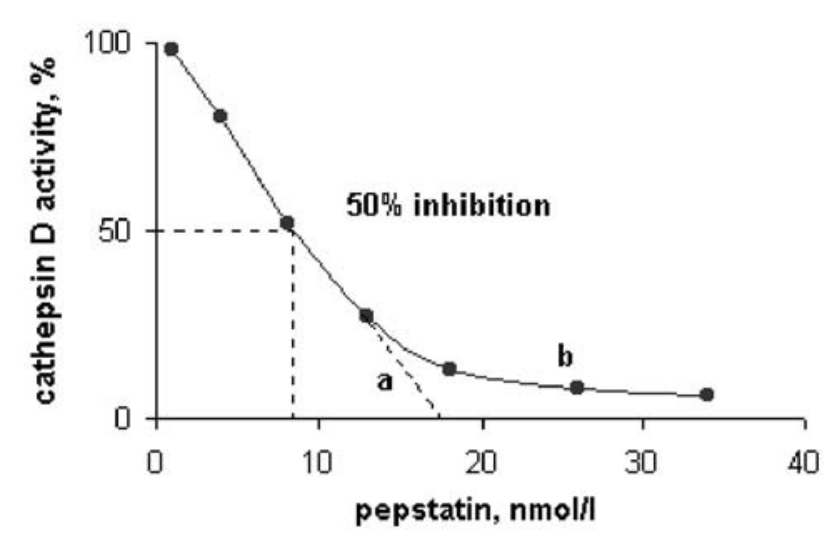

Fig. 20. Inhibitor curve obtained by addition of increasing amounts of pepstatin to the cathepsin D; substrate - hemoglobin; titration curve: a - ideal, b - real.

globin [138] are most sensitive to cathepsin D action. The enzyme activity is reflected by the quantity of TCA-soluble tyrosine released from these substrates. Cathepsin D shows a considerably lower affinity as compared to other proteins (Table 3). The activity of this protease is also determined using micromolecular synthetic substrates [140-143].

The content of active cathepsin D in tissue homogenates in blood plasma and body fluids is determined by means of a graph showing the relationship between the activity and the level of highly-purified cathepsin D preparation [144] (Fig. 19). Another method employed to assess cathepsin D content is titration of the catalytic site using pepstatin and its derivatives [107,145] (Fig. 20). Pepstatin binds to cathepsin D in the mole ratio of 1:1. The total content of cathepsin $\mathrm{D}$, inactive and active in tissues and body fluids, is determined by means of specific antibodies $[18,146]$.

Cell and tissue localization of cathepsin D is performed using the immunohistoenzymatic methods, with specific antibodies [147-150] or labeled pepstatin [151153].

Differences in substrate specificity, $\mathrm{pH}$ optima, sensitivity to activators and inhibitors, and in antigen properties allow identification of cathepsin D and determination of its activity and concentration in tissue homogenates, blood plasma and body fluids [154-157].

\section{Final comments}

Cathepsin D plays an essential role in metabolism as an enzyme degrading the exhausted cell proteins and restoring their amino acids to syntheses, as well as a modulator of proteolysis, activating precursor forms of many proteases and inactivating their inhibitors. The role of cathepsin D in biomedical sciences extends its involvement in many pathological processes such as 
apoptosis, inflammatory states, rheumatic diseases, neoplasms, muscle dystrophy, Alzheimer disease, as well as in their diagnostics [158-168]. The use of inhibitors of cathepsin D biosynthesis, activation and its active form allows regulation of cathepsin D activation.

Human preprocathepsin, procathepsin and cathepsin $\mathrm{D}$ differ from their equivalents isolated from the mammalian tissue in a number of particulars concerning the amino acid sequence, posttranslatory modifications and conformatory structure [169]. Due to the differences, human anti-cathepsin D antibodies do not react with cathepsin $\mathrm{D}$ of other species [170].

\section{References:}

[1] Hedin SG. Investigation on the proteolytic enzymes of the sleen of the ox. J Physiol. 1904;30:155-157.

[2] Wilstätter R, Bamann E. Üler die proteasen der magenschleimhaut. Erste abhandlung über die enzyme der leukocyten. Z Physiol Chem. 1928;180:127-143.

[3] Anson ML. The estimation of cathepsin with hemoglobin and partial purification of cathepsin. J Gen Physiol. 1937;20:565574.

[ 4] Tallan HH, Jones ME, Fruton JS. On the proteolytic enzymes of animal tissue. X. Beef spleen cathepsin C. J Biol Chem. 1952;194:793-805.

[5] De Duve C, Pressman BC, Gianetto R, Wattiaux R, Appelmans F. Tissue fractionation studies. 6. Intracellular distribution pattern of enzymes in rat liver tissue. Biochem J. 1955; 60:604-617.

[ 6] Czystohorski T. Pepsin or cathepsin? Pol Tyg Lek. 1955;10:9 41-943.

[ 7] Press EM, Porter RR, Cebra J. The isolation and properties of a proteolytic enzyme, cathepsin $\mathrm{D}$, from booine spleen. Biochem J. 1960;74:501-514.

[ 8] Redecker B, Heckendorf B, Grosch HW, Mersmann G, Hasilik A. Molecular organization of the human cathepsin D gene. DNA Cell Biol. 1991;10:423-431.

[9] May FE, Smith DJ, Westley BR. The human cathepsin Dencoding gene is transcribed from an estrogen-regulated and a constitutive start point. Gene. 1993;134:277-282.

[10] Scorborongh PE, Richo GR, Kay J, Conner GE, Dunno BM. Comparison of kinetic properties of native and recombinand human cathepsin D. Adv Exp Med Biol. 1991;306: 343-347.

[11] Sheikh MS, Augereau P, Chalbos D, Garcia M, Rochefort H. Retinoid regulation of human cathepsin D gene expression. $J$ Steroid Biochem Molec Biol. 1996;57:283-291.

[12] Wang F, Duan R, Chirgwin J, Safe SH. Transcriptional activarion of cathepsin $\mathrm{D}$ gene expression by growth factors. $J$ Med Endocrinol. 2000;24:193-202.

[13] Devasagayam TPA, Pushpendran CK, Eapen J. Cycloheximide-induced inhibition of cathepsin D activity in suckling and adult rats. Biochem Int. 1981;3:55-60.

[14] Musi M, Tessitore L, Bonelli G, Kazakova OV, Baccino FM. Changes in rat liver immunoreactive cathepsin D after cycloheximide. Biochem Int. 1985;10:283-290.

[15] Stancikova M, Frysak Z, Trnavsky K. Effect of colchicine on the activity of cathepsin B and D in liver cirrhosis. Acta Med Hung. 1987;44:181-188.

[16] Yamamoto K. Cathepsin E and cathepsin D. In: Turk V, ed. Proteases. New perspectives. Birkhäuser Verlag Basel. 1999:59-71.
[17] Huang JS, Huang SS, Tang J. Cathepsin D isozymes from porcine spleens. Lagre scale purification and polypeptide chain arrangements. J Biol Chem. 1979;254:11405-11417.

[18] Ikeda K, Suzuki H, Okano T, Nakagawa S. Human spleen cathepsin D: its characterization and localization in human spleen. Int J Biochem. 1989;21:317-326.

[19] Kregar I, Urh I, Smith R, Umezawa H, Turk V. Isolation of cathepsin D on pepstatin-agarose resin. In: Turk V, Marks N, eds. Intracellular protein catabolism II. Plenum Press NY. 1977:250-254.

[20] Stewart AJ, Piggott NH, May FEB, Westley BR. Mitogenic activity of procathepsin $\mathrm{D}$ purified for conditioned medium of breast cancer cells by affinity chromatography on pepstatinyl agarose. Int J Cancer. 1994;57:715-718.

[21] Gubensek F, Barstow I, Kregar I, Turk V. Rapid isolation of cathepsin D by affinity chromatography on the immobilized synthetic inhibitor. FEBS Lett. 1976;71:42-44.

[22] Gacko M, Minarowska A, Karwowska A, Minarowski Ł. Cathepsin D inhibitors. Folia Histochem Cytobiol. 2007;45: 291-313.

[23] Smith R, Turk V. Cathepsin D: rapid isolation by affinity chromatography on hemoglobin-agarose resin. Eur $J$ Biochem. 1974;48:245-254.

[24] Wittlin S, Rösel J, Stover DR. One-step purification of cathepsin D by affinity chromatography using immobilized propeptide sequences. Eur J Biochem. 1998;252:530-536.

[25] Conner GE. Isolation of procathepsin D from mature cathepsin D by pepstatin affinity chromatography. Antocatalytic proteolysis of the zumogen from of the enzyme. Biochem $J$. 1989;263:601-604.

[26] Beyer MB, Dunn BM. Self-activation of recombinant human lysosomal procathepsin $\mathrm{D}$ at a newly engineered cleavage junction, "short" pseudocathepsin D. J Biol Chem. 1996;271:15590-15596.

[27] Conner GE, Udey JA. Expression and refolding of recombinant human fibroblast procathepsin D. DNA Cell Biol. 1990;9:1-9.

[28] Gopalakrishan MM, Gosch HW, Locatelli-Hoops S, Werth N, Smolenova E, Nettersheim M, Sandhoff K, Hasilik A. Purified recombinant human prosoposin forms oligomers that bind procathepsin D and affeet its autoactivation. Biochem $J$. 2004;383:507-515.

[29] Barrett AJ. Cathepsin D. Purification of isoenzymes from human and chicken liver. Biochem J. 1970;117:601-607.

[30] Barrett AJ. Human cathepsin D. Adv Exp Med Biol. 1979;95:291-300

[31] Fusek M, Baudys M, Metcolf P. Purification and crystallization of human cathepsin - D. J Mol Biol. 1992;226:555-558.

[32] Gulnik S, Baldwin ET, Tarasova N, Erickson J. Human liver cathepsin D. Purification, crystallization and preliminary Xray diffraction analysis of a lysosomal enzyme. $J$ Mol Biol. 1992;227:265-270.

[33] Koelsch O, Metcalf P, Vetvicka V, Fusek M. Human procathepsin D: three-dimensional model and isolation. Adv Exp Med Biol. 1995;362:273-278.

[34] Afting EG. Becler ML. Two-step affinity-chromatographic purification of cathepsin D from pig myometrium with high yield. Biochem J. 1981;197:519-522.

[35] Contractor SF, Manson RM, Oakey M. Purification and properties of human placental cathepsin D. Placenta. 1982;3:4556.

[36] Pohl J, Bures L, Slavik K. Isolation and characterization of cathepsin D from human gastric mucosa. Coll Chech Chem Commun. 1981;46:3302-3313.

[37] Azaryan A, Akopyan T, Buniatian H. Cathepsin D from human train: purification and multiple forms. Biomed Biochim Acta. 1983;42:1237-1246. 
[38] Lundblad G, Bernbäck ML, Widemann C. Proteolytic activity in human thyroid extracts. I. Purification and properties of some proteinases. Acta Cem Scand. 1966;20:675-688.

[39] Ishikawa I, Cimasoni G. Isolation of cathepsin D from human leucocytes. Biochim Biophys Acta. 1977;480:228-240.

[40] Metaclf P, Fusek M. Two crystal structure for cathepsin D: the lysosomal targeting signal and active site. EMBO J. 1993;12:1293-1302.

[41] Pain RH, Lah T, Turk V. Dematuration studies of aspartic proteinases. Biochem Soc Transact. 1985;13:1032-1035.

[42] Turk V, Kregar I, Gubensek F, Lapanje S, Urh I, Kovacic M. Studies of bovine spleen cathepsin D. Acta Biol Med. 1977;36:1531-1535.

[43] Erickson AH. Biosynthesis of lysosomal endopeptidases. $J$ Cell Biochem. 1989;40:31-41.

[44] Fusek M, Vetvicka V. Cathepsin D. In: Fusek M, Vetvicka V, eds. Aspartic proteinases: physiology and patology. CRC Press Boca Ratton. 1995:143-184.

[45] Giselmann V, Hasilik A, von Figura K. Processing of human cathepsin D in lysosomes in vitro. J Biol Chem. 1985;260: 3215-3220.

[46] Gieselmann VR, Pohlmann A, Hasilik A, Figura K. Biosynthesis and transport of cathepsin D in cultured human fibroblast. J Cell Biol. 1983;97:1-5.

[47] hasilik A. The early and late processing of lysosomal enzymes: proteolysis and compartmentation. Experientia. 1992;48:130-151.

[48] Schulze-Lohoff E, Hasilik A, Figura K. Cathepsin D precursors in clathrin-coated organelles from human fibroblast. $J$ Cell Biol. 1985;101:824-829.

[49] Fortenberry SC, Schorey JS, Chirgwin JM. Role of glycosylation in the expression of human procathepsin D. J Cell Sci. 1995;108:2001-2006.

[50] Imperiali B, Rickert KW. Conformational implications of asparagines-linked glycosylation. Proc Natl Acad Sci USA. 1995;92:97-101.

[51] Shewale JG, Rakahashi T, Tang J. The primary structure of cathepsin $\mathrm{D}$ and the implications for its biological functions. In: Kostka V, ed. Aspartic proteinases and their inhibitors. Walter de Gruyter Berlin. 1985:101-116.

[52] Isidoro C, Hummel M, Baccino F, Hasilik A. The respective role of mannose-6-phosphate residues and of prosaposin in the segregation of lysosomal procathepsin D. In: Hopsu-Havu VK, ed. Proteolysis in cell function. IOS Press Amsterdam. 1997:234-241.

[53] Baranski TJ, Cantor A, Kornfeld S. Lysosomal enzyme phosphorylation I. Protein recognition determination in both lobes of procathepsin D mediate its interaction with UDP-GlcNac: lysosomal enzyme $\mathrm{N}$-acetylglucosamine-1-phosphotransferase. J Biol Chem. 1992;267:23342-23348.

[54] Cantor S, Kornfeld S. Phosphorylation of Asn-linked oligosaccharides located at novel sites on the lysosomal enzyme cathepsin D. J Biol Chem. 1992;267:23357-23363.

[55] Boker C, von Figura K, Hille-Rehfeld A. The carboxy-terminal peptides of $46 \mathrm{kDa}$ and $300 \mathrm{kDa}$ mannose 6-phosphate receptors share partial sequence homology and contain information for sorting in the early endosomal pathway. J Cell Sci. 1997; 110:1023-1032.

[56] Conner GE. The role of the cathepsin D propeptide in sorting to the lysosome. J Biol Chem. 1992;267:21738-21745.

[57] Grassel S, Hasilik A. Human cathepsin D precursor is associated with a $60 \mathrm{kDa}$ glycosylated polypeptide. Biochim Biophys Res Commun. 1992;18:276-282.

[58] Hasilik A, Klein U, Waheed A, Strecker G, von Figura K. Phosphorylated oligosaccharides in lysosomal enzymes: indutification of $\alpha$-N-acetyloglucosamine(1)phosphor(6) mannose diester groups. Proc Natl Acad Sci USA. 1980;77: 7074-7078.
[59] Hasilik A, Neufeld EF. Biosynthesis of lysosomal enzymes in fibroblasts. Phosphorylotion of mannose residues. J Biol Chem. 1989;255:4946-4950.

[60] Sahagian GG. The mannose 6 phosphate receptor: function, biosynthesis and translocation. Biol Cell. 1984;51:207-214.

[61] Hille-Rehfeld A. Mannose-6-phosphate receptors in sorting and transport of lysosomal enzymes. Biochim Biophys Acta. 1995;1241:177-104.

[62] Horst M, Mares M, Zabe M, Hummel M, Wiedernders B, Kirsche H, Hasilik A. Synthesis phosphorylated oligosaccharides in lysosome in enhanced by fusion to cathepsin D. J Biol Chem. 1993;268:19690-19696.

[63] Erickson AH, Conner GE, Bloble G. Biosynthesis of a lysosomal enzyme. Partial structure of two transient and functionally distinct NH2-terminal sequences in cathepsin D. J Biol Chem. 1981;256:11224-11231.

[64] Faust PL, Kornfeld S, Chirgwin JM. Cloning and sequence analysis of cDNA for human cathepsin D. Proc Natl Acad Sci USA. 1985;82:4910-4914.

[65] Kobayashi T, Honke K, Gasa S, Fujii T, Maguchi S, Miyazaki T, Makita A. Proteolytic processing sites producing the mature from of human cathepsin D. Int J Biochem. 1992;24: $1487-1492$.

[66] Lah T, Turk V. Autolysis studies of cathepsin D. HoppeSeyler's Z Physiol Chem. 1982;363:247-254.

[67] Wittlin S, Rosel J, Hofmann F, Stover DR. Mechanism and kinetics of procathepsin D activation. Eur J Biochem. 1999; 265:384-393.

[68] Yonezawa S, Takahashi T, Wang X, Wong RNS, Hartsuck JA, Tang J. Structure at the proteolytic processing region of cathepsin D. J Biol Chem. 1988;263:16504-16511.

[69] Richio G, Conner GE. Proteolytic activation of human procathepsin D. Adv Exp Med Biol. 1991;306:289-296.

[70] Samarel AM, Ferguson AG, Decker RS, Lesch M. Effects of cysteine protease inhibitors on rabbit cathepsin D maturation. Am J Physiol. 1989;257:C1069-C1079.

[71] Richo GR, Conner GE. Structural requirements of procathepsin D activation and maturation. J Biol Chem. 1994;269: 14806-14812.

[72] Sapolsky AI, Woessner JF. Multiple forms of cathepsin D from bovine uterus. J Biol Chem. 1972;247:2069-2076.

[73] Fortenberry SC, Chirgwin JM. The propeptide is nonessential for the expression of human catepsin D. J Biol Chem. 1995;270:9778-9782.

[74] Scarborough PE, Dunn BM. Redesign of the substrate specificity of human cathepsin D: the dominant role of position 287 in the S2 subside. Protein Eng. 1994;7:495-502.

[75] Van Noort JM, van der Drift ACM. The selectivity of cathepsin D suggests an involvement of the enzyme in the generation of T-cell epitopes. $J$ Biol Chem. 1989;264:14159-14164.

[76] Ferguson JB, Andrews JR, Voynick IM, Fruton JS. The specificity of cathepsin D. J Biol Chem. 1973;248:6701-6708.

[77] Scarborough PE, Guruprasad K, Topham C, Richo GR, Conner GE, Blundell TL, Dunn BM. Exploration of subside binding specificity of human cathepsin D trough kinetics and rulebased molecular modeling. Prot Sci. 1993;2:269-276.

[78] Kussendrager KD, Jong Y, Bouma JMW, Gruber M. The digestion of the $\mathrm{B}$ chain of oxidized insulin by extracts of rat liver lysosomes. Biochim Biophys Acta. 1972;279:75-86.

[79] Worowski K, Ostrowska H. Cathepsin D. Post Biol Kom. 1980;7:119-147.

[80] Hunt LT, Dayhoff O. The occurence in proteins of the tripeptides Asn-X-Thr and Asn-X-Ser and bound carbohydrate. Biochem Biophys Res Commun. 1970;39:757-765.

[81] Bjelic S, Aqvist J. Catelysis and linear free energy relationships in aspartic proteases. Biochemisty. 2006;45:77097723. 
[82] Conner GE, Richo G. Isolation and characterization of a stable activation intermediate of the lysosomal aspartyl protease cathepsin D. Biochemistry. 1992;31:1142-1147.

[83] Cooper JB. Aspartic proteinases in disease: a structural perspective. Curr Drug Targets. 2002;3:155-173.

[84] Nduwimana J, Guenet L, Dorval I, Blayau M, Le Gall JY, Le Treut A. Proteases. Ann Biol Clin. 1995;53:251-264.

[85] Veerapandian B, Cooper JB, Sali A, Blundell TL, Rosati RL, Dominy BW, Damon DB, Hoover DJ. Direct observation by X-ray analysis of the tetrahedral "intermediate" of aspartic proteinases. Protein Sci. 1992;1:322-328.

[86] Xie D, Gulnik S, Collins L, Gustchina E, Suvorov L, Erickson JW. Dissection of the $\mathrm{pH}$ dependence of inhibitor binding energetics for an aspartic protease: direct measurement of the protonation states of the catalytic aspartic acid residues. Biochemistry. 1997;36:16166-16172.

[87] Huber R, Bennett WS. Enzymes as biological catalysts. In: Hoppe, Lohmann W, Mark1 H, Ziegler H, ed. Biophysics. Springer-Verlag, Berlin. 1983:372-384.

[88] Jencks WP. Economics of enzyme catalysis. Cold Spring Harbor Symp Puant Biol. 1987;52:65-73.

[89] Majer P, Collins JR, Gulnik SV, Erikson JW. Structuralbased specificity mapping of human cathepsin D using statine-based inhibitors. Prot Sci. 1997;6:1458-1466.

[90] Dionyssiou-Asteriou A, Rakitzis ET. Activation of cathepsin D by glycine ethyl ester. Biochem J. 1979;177:355-356.

[91] Watabe S, Yago N. Phospholipids activate cathepsin D. Biochem Biophys Res Commun. 1983;110:934-939.

[92] Watabe S, Ikeda T, Yago N. Activation of cathepsin D by polyanionic compounds. Bioch Molec Biol Int. 1996;39:703710.

[93] Huang JS, Tang J. Preliminary evidence for a protein-activator of cathepsin D from bovine spleen. Fed Proc. 1977;36:892 abstract 3272 .

[94] Masa M, Maresova L, Vondrasek J, Horn M, Jezek J, Mares M. Cathepsin D propeptide: mechanism and regulation of its interaction with the catalytic core. Biochemistry. 2006;45: 15474-15482.

[95] Puizdar V, Turk V. Cathepsinogen D: characterization and activation to cathepsin D and inhibitory peptides. FEBS Lett. 1981;132:299-304.

[96] Fusek M, Mares M, Vagner J, Voburka Z, Baudys M. Inhibition of aspartic proteinases by propart peptides of human procathepsin D and chicken pepsinogen. FEBS Lett. 1991;287: 160-162.

[97] Lach T, Vihar M, Turk V. Interaction of cathepsin D and pepsin with $\alpha 2$-macroglobulin. In: Kostka V, ed. Aspartic proteinases and their inhibitors. Walter de Gruyter, Berlin. 1985:485-490.

[98] Thomas DJ, Richards AD, Kay J. Inhibition of aspartic proteinases by $\alpha 2$-macroglobulin. Biochem J. 1989;259:905-907.

[99] Kopitar-Jerala N, Puizdar V, Berbic S, Zavasnik-Bergant T, Turk V. A cathepsin D specific monoclonal antibody. Immunol Lett. 2001;77:125-126.

[100] Weston PD. A specific antiserum to lylosomal cathepsin D. Immunology. 1969;17:421-428.

[101] Avila JL, Convit J. Inhibition of leucocytic lysosomal enzymes by glicosaminoglycans in vitro. Biochem J. 1975; 152:57-64.

[102] Shibata M, Koike M, Waguri S, Zhang G, Koga T, Uchiyama Y. Cathepsin D is specifically inhibited by deoxyribonucleic acids. FEBS Lett. 2002;517:281-284.

[103] Tang J. Specific and irreversilde inactivation of pepsin by substrate - like epoxides. J Biol Chem. 1971;246:4510-4517.

[104] Keilova H. Inhibiton of cathepsin D by diazoacetylnorleucine methyl ester. FEBS Lett. 1970;6:312-314.

[105] Dumas J, Brittelli D, Chen J, Dixon B, Hatoum-Mokdad H. Synthesis and structure activity relationships of novel small molecule cathepsin D inhibitors. Bioorg Med Chem Lett. 1999;9:2531-2536

[106] Jupp RA, Dunn BM, Jacobs JW, Vlasuk G, Arcuri KE, Veber DF, Perlow DS, Payne LS, Boger J, Laszlo S, Chakravarty PK, Broekes J, Hangauer DG, Ondeyka D, Greenlee WJ, Kay J. The selectivity of statine-based inhibitors against various human aspartic proteinases. Biochem J. 1990;265:871-878.

[107] Knight CG, Barrett AJ. Interaction of human cathepsin D with the inhibitor pepstatin. Biochem J. 1976;155:117-125.

[108] Dash C, Kulkarni A, Dunn B, Rao M. Aspartic peptidase inhibitors: implications in drug development. Crit Rev Biochem Molec Biol. 2003;38:89-119.

[109] Lenarcic B, Turk V. Tyreoglobulin type-1 domains in equistatin inhibit both papain-like cystein proteinases and cathepsin D. J Biol Chem. 1999;274:563-566.

[110] Worowski K. Inhibitory komórkowych enzymów proteolitycznych. Post Biol Kom. 1976;3:51-74.

[111] Huisman W, Lanting L, Doddema HJ, Bouma JMW, Gruber M. Role of individual cathepsins in lysosomal protein digestion as tested by specific inhibitors. Biochim Bioplys Acta. 1974;370:297-307.

[112] Huo S, Wang J, Cieplak P, Kollman PA, Kuntz ID. Molecular dynamics and free energy analysis of cathepsin Dinhibitor interactions: insight into structure-based ligand design. J Med Chem. 2002;45:1412-1419.

[113] Leung D, Abbenate G, Fairlie DP. Protease inhibitors: current status and future prospects. $J$ Med Chem. 2000;43:305-341.

[114] Rich DH. Inhibitors of aspartic proteinases. In: Barrett AJ, Salvesen G, eds. Proteinase inhibitors. Elsevier, Amsterdam. 1986:179-217.

[115] Tumminello FM, Bernacki RJ, Gebbia N, Leto G. Pepstatins: aspartic proteinase inhibitors having potential therapeutic applications. Med Res Rev. 1993;13:199-208.

[116] Kimura H, Tsudzuki T, Murachi T. Proteolytic degradation of hemoglobin-haptoglobin compleks by lysosomal enzymes from rat liver. $J$ Biol. 1975;77:909-912.

[117] Bohley P. Intracellular proteolysis. In: Neuberger A, Brocklehurst K, eds. Hydrolytic enzymes. Elsevier, Amsterdam. 1987:307-330.

[118] Cuervo AM, Dice JF. Lysosomes, a meeting point of proteins, chaperones, and proteases. J Mol Med. 1998;76:6-12.

[119] Cuervo AM, Palmer A, Rivett AJ, Knecht E. Degradation of proteasomes by lysosomes in rat liver. Eur J Biochem. 1995; 227:792-800

[120] Kominami E, Ueno T, Muno D, Katunuma N. The selective role of cathepsin B and D in the lysosomal degradation of endogenous and exogenous proteins. FEBS Lett. 1991;287: 189-192.

[121] Dingle JT. The immunoinhibition of cathepsin D-mediated cartilage degradation. In: Barrett A, Dingle JT, eds. Tissue Proteinases. North-Holland Publ Co, Amsterdam. 1971:313324.

[122] Scott PG, Pearson H. Cathepsin D: specificity of peptide bond cleavage in type I collagen and effects on the type III collagen and procollogen. Eur J Biochem. 1981;114:59-62.

[123] Kopitar M, Brzin J, Drobnic-Kosorek M, Babnik J, Locnikar P, Rurk V, Giraldi T, Sava G. some further characteristics of endogenous proteinase inhibitors. Acta Biol Med Germ. 1982;41:75-82.

[124] Lenarcic B, Krasovec M, Ritonja A, Olafsson I, Turk V. Inactivation of human cystatin $\mathrm{C}$ and kininogen by human cathepsin D. FEBS Lett. 1991;280:211-215.

[125] Pimenta DC, Chen VC, Chao J, Juliano MA, Juliano L. $\alpha_{1^{-}}$ antychumotrypsin and kallistatin hydrolysis by human cathepsin D. J Protein Chem. 2000;19:411-418.

[126] Rowan AD, Mason P, Mach L, Mort JS. Rat procathepsin B. Proteolytic processing to the mature form in vitro. $J$ Biol Chem. 1992;267:15993-15999. 
[127] Van der Stappen JWJ, Williams AC, Maciewicz RA. Activation of cathepsin B, secreted by a colorectal cancer cell line requires low $\mathrm{pH}$ and is mediated by cathepsin $\mathrm{D}$. Int $J$ Cancer. 1996;67:547-554.

[128] Wiederanders B, Kirschke H. The processing a cathepsin L precursor in vitro. Arch Biochem Biophus. 1989;272:516521.

[129] Darby NJ, Smyth DG. Endopeptidases and prohormone processing. Biosci Rep. 1990;10:1-14.

[130] Kageyama T. Rabbit procathepsin E and cathepsin E. Eur J Biochem. 1993;216:717-728.

[131] Fruitier I, Garreau I, Piot JM. Cathepsin D is a good candidate for the specific release of stable hemorphin from hemoglobin in vivo: VV-hemorphin-7. Biochem Biophys Res Commun. 1998;246:719-724.

[132] Garreau I, Cucumel K, Dagouassat N, Zhao P, Gupo A, Piot JM. Hemorphin peptides are released from hemoglobin by cathepsin D. Radioimmunoassay against the C-part of V-Vhemorphin-7: an alternative assay for the cathepsin D activity. Peptides. 1997;18:293-300.

[133] Reeves JP. The mechanism of lysosomal acidification. In: Dingle JT, Dean RT, Sly W, eds. Lysosomes in biology and pathology. Elsevier, Amsterdam. 1984:175-199.

[134] Kazakova OV, Orekhovich V. Some properties of cathepsins chemically fixed to carriers. Int J Pept Protein Res. 1975; 7:23-29.

[135] Diment S, Leech MS, Stahl PD. Cathepsin D in membraneassociated in macrophage endosomes. J Biol Chem. 1988; 263:6901-6907.

[136] Marciniszyn J, Hartsuck JA, Tang J. Mode of inhibition of acid proteases by pepstatin. J Biol Chem. 1976;251:70887094.

[137] Karwowska A, Chlabicz M. Bovine globin as substrate of cathepsin D. In preparation.

[138] Roth JA, Losty K, Wierbick E. Assay of proteolytic enzyme activity using a 14C-labelet hemoglobin. Anal Biochem. 1971;42:214-221

[139] Lebez D, Kopitar M, Turk V, Kregar I. Comparison of properties of cathepsin $\mathrm{D}$ and $\mathrm{E}$ with some new cathepsine. In: Barrett AJ, Dingle JT, eds. Tissue proteinases. Nrth-Holland Publ Co, Amsterdam. 1971:167-176.

[140] Dunn BM, Jiminez M, Parten BF, Valler CE, Rolph J, Kay J. a systematic series of synthetic chromophoric substrates for aspartic proteinases. Biochem J. 1986;237:899-906.

[141] Gulnik S, Suvorov L, Majer P, Collins J, Kane B, Johnson DG, Erickson J. Design of sensitive fluorogenic substrates for human cathepsin D. FEBS Lett. 1997;413:379-384.

[142] pimento DC, Oliveira A, Juliano MA, Juliano L. Sunstrate specificity of human cathepsin D using internally quenched fluorescent peptides derived from reactive site loop of kallistatin. Biochim Biophys Acta. 2001;1544:113-122.

[143] Yasuda Y, Kageyama T, Akamine A, Shibata M, Kominami E, Uchiyama Y, Yamamoto K. Characterization of new fluorogenic substrates for the rapid and sensitive assay of cathepsin E and cathepsin D. J Biochem. 1999;125:11371143.

[144] Turk V, Lah T, Kregar I. Cathepsin D, cathepsin E. In: Bergmeyer HU, ed. Methods of enzymatic analysis. Verlag Chemie, Weinheim. 1984:211-222.

[145] Knight CG. Active site titration of peptidases. Meth Enzymol. 1995;248:85-101.

[146] Brouillet JP, spyratos F, Hacene K, Fauque J, Freiss G, Dupont F, Maudelonde T, Rochefort H. Immunoradiometric assay of pro-cathepsin D in breast cancer cytosol: relative prognostic value versus total cathepsin D. Eur $J$ Cancer. 1993;29A:1248-1251.

[147] Ravdin PM, Tandon ASK, Allred DC. Chathepsin D by western blotting and immunohistochemistry: failure to con- firm correlations with prognosis in node-negative breast cancer. J Clin Oncol. 1994;12:468-474.

[148] Reid WA, Valler MJ, Kay J. Immunolocalisation of cathepsin D in normal and neoplastic human tissues. J Clin Pathol. 1986;39:1323-1330.

[149] Roger P, Montcourrier P, Maudelonde T, Brouillet JP, Pages A, Laffargue F, Rochefort H. Cathepsin D immunostaining in paraffin-embedded breast cancer cells and macrophages. Correlation with cytosolic assay. Human Pathol. 1994;25: 863-871.

[150] Sasaki H, Saku Y, Kato K, Yamamoto K. Quantitation and immunohistochemical localization of cathepsin E and D in rat tissues and blood cells. Biochim Biophys Acta. 1989;991: 367-375.

[151] Matthews ITW, Decker RS, Knight CG. Bimane-labeled pepstatin, a fluorescent probe for the subcellular location of cathepsin D. Biochem J. 1981;199:611-617.

[152] Yamato S, Hirabayashi Y, Sigihara H. An improved procedure for the histochemical demonstration of cathepsin D by the mercury-labeled pepstatin method. Stain Technol. 1984; 59:113-120.

[153] Yamato S, Hirabayashi Y, Sugihara H, Uematsu H. Electron microscopic visualization of cathepsin D using mercurylabeled pepstatin as an enzyme inhibitor. $J$ Histochem Cytochem. 1982;30:1228-1234.

[154] Kay J, Tatnell PJ. Cathepsin E. In: Barrett AJ, Rawling ND, Woessner JF, eds. Handbook of proteolytic enzymes. Elsevier, Amsterdam. 2004;1:33-38

[155] Ng KKS, Petersen MM, Charney MM, Garen C, Zalatoris JJ, Rao-Naik C, Dunn BM, Martzen MR, Peansky RJ, James MNG. Structural basis for the inhibition of porcine pepsin by Ascaris pepsin inhibitor-3. Nat Struct Biol. 2000;7:653657.

[156] Willenbucher J, Hofle W, Lucius R. The filarial antigens Av33/Ov33-3 show stricking similarities to the major pepsin inhibitor from Ascaris suum. Mol Biochem Parasitol. 1993; 57:349-351.

[157] Yamamoto K, Kamata O, Katsuda N, Kato K. Immunochemical difference between cathepsin D and cathepsin Elike enzyme from rat spleen. J Biochem. 1980;87:511-516.

[158] Berchem G, Glondn M, Gleizes M, Brouillet JP, Vignon F, Garcia M, Liaudet-Coopman E. Cathepsin D affects multiple tumor progression steps in vivo: proliferation, angiogenesis and apoptosis. Oncogene. 2002;21:5951-5955.

[159] Chwieralski CE, Wlte T, Buhling F. Cathepsin-regulated apoptosis. Apoptosis. 2006;11:143-150.

[160] Cybulski M, Berbeć H. rola katepsyny D w progresji nowotworowej. Post Biochem. 2001;47:224-231.

[161] Davidson Y, Gibbons L, Pritchard A. Genetic associations between cathepsin $\mathrm{D}$ exon $2 \mathrm{C} \rightarrow \mathrm{T}$ polymorphism and Alzheimer's disease, and pathological correlations with genotype. J Neurol Neurosurg Psychiat. 2006;77:515-517.

[162] Fusek M, Vetvicka V. Dual role of cathepsin D: ligand and protease. Biomed Papers. 2005;149:43-50.

[163] Heinrich M, Neumeyer J, Jakob M, Halls C, Tchikov V, Winoto-Morbach S, Wickel M, Schneider-Brachert W, Trauzoll A, Hethke A, Schulze C. Cathepsin D links TNFinduced acid sphingomyelinase to Bid-mediated caspase-9 and -3 activation. Cell Death Differ. 2004;11:550-563.

[164] Leto G, Tumminello FM, Crescimanno M, Flandina C, Gebbia N. Cathepsin D expression levels in nongynecological solid tumors: clinical and therapeutic implications. Clin Exp Metastas. 2004;21:91-106.

[165] Liaudet-Coopman E, Beaujonin M, Derocq D, Garcia M, Glondu-Lassis M, Laurent-Matha V, Prebois C, Rochefort H, Vigon F. Cathepsin D: newly discovered functions of a long-standing aspartic protease in cancer and apoptosis. Cancer Lett. 2006;237:167-179. 
[166] Minarowska A, Minarowski K, Karwowska A, Gacko M. Regulatory role of cathepsin D in apoptosis. Folia Histochem Cytobiol. 2007;45:159-163.

[167] Roberg K, Kaged K, Ollinger K. Microinjection of cathepsin $\mathrm{D}$ induces caspase-dependent apoptosis in fibroblasts. Am J Pathol. 2002;16:89-96.

[168] Warwas M, Taurowska E. Znaczenie katepsyny D w diagnostyce choroby nowotworowej. Post Hig Med. Dośw. 1993;47:277-288.

[169] Komai T, Kawabata C, Amano M, Lee BR, Ichima E. Tadarepsin, a new cathepsin D from hepatopancreas of Japanese common squid (Todarodes pacificus). Biochem Physiol Part B. 2004;137:373-382.
[170] Weston PD, Poole AR. Antibodies to enzymes and their uses, with specific reference to cathepsin D and other lysosomal enzymes. In: Dingle JT, ed. Lysosomes in biology and pathology. North Holland Elsevier, Amsterdam. 1973;3:425464.

[171] Baldwin ET, Bhat TN, Gulnik S, Hosur MV, Sowder RC 2nd, Cachau RE, Collins J, Silva AM, Erickson JW. Crystal structures of native and inhibited forms of human cathepsin D: implications for lysosomal targeting and drug design. Proc Natl Acad Sci USA. 1993;15;90(14):6796-800.

[172] Lee AY, Gulnik SV, Erickson JW. Conformational switching in an aspartic proteinase. Nat Struct Biol. 1998;5(10):866-71.

Submitted: 21 August, 2007 Accepted after reviews: 28 December, 2007 